\title{
PENGEMBANGAN MODUL SEMPOA SEBAGAI ALTERNATIF DALAM MATA KULIAH INOVATIF MATEMATIKA
}

\author{
Andri Anugrahana \\ PGSD, FKIP, Universitas Sanata Dharma \\ andrianugrahana@gmail.com
}

\begin{abstract}
This research is a research development using development research methods that are oriented to the development of learning products namely the abacus module. The product produced in the form of an Abacus module is expected to be able to help in innovative lectures of elementary school teacher candidates. The purpose of this study was to determine: (1) describe the development of the abacus module with the Dick \& Carey model, (2) determine the quality of the product produced, the abacus module. This research is a research development and the instruments used are questionnaires and interview guidelines. Data were analyzed with qualitative descriptive analysis techniques and quantitative descriptive statistical analysis. The results of the subject matter expert test indicate that the abacus module is in good qualifications. Abacus experts assess teaching materials are in good qualifications. Individual trial results indicate teaching materials are of sufficient qualification. Field test results indicate that teaching materials are well qualified.
\end{abstract}

Keywords: : module, abacus, development

\begin{abstract}
Abstrak
Penelitian ini merupakan penelitian pengembangan menggunakan metode penelitian pengembangan yaitu berorientasi pada pengembangan produk pembelajaran yaitu Modul sempoa. Produk yang dihasilkan berupa modul Sempoa ini diharapkan dapat membantu dalam perkuliahan inovatif matematika calon guru sekolah dasar. Tujuan penelitian ini adalah untuk mengetahui: (1) mendeskripsikan pengembangan modul sempoa dengan model Dick \& Carey, (2) mengetahui kualiatas dari produk yang dihasilkan yaitu modul sempoa. Penelitian ini merupakan penelitian pengembangandan instrumen yang digunakan adalah angket dan pedoman wawancara. Data dianalisis dengan teknik analisis deskriptif kualitatif dan analisis statistik deskriptif kuantitatif. Hasil uji ahli isi mata kuliah menunjukkan bahwa modul sempoa berada pada kualifikasi baik. Ahli sempoa menilai bahan ajar berada pada kualifikasi baik. Hasil uji coba perorangan menunjukkan bahan ajar berada pada kualifikasi cukup. Hasil uji lapangan menunjukkan bahwa bahan ajar berkualifikasi baik.
\end{abstract}

Kata kunci: modul, sempoa, pengembangan

Matematika memiliki peran penting dalam kehidupan dan perkembangan pengetahuan maupun teknologi. Alasan matematika dianggap sebagai mata pelajaran yang penting karena matematika mampu membekali mahasiswa untuk berfikir logis, analisis. Hal ini sejalan dengan yang diungkapkan oleh Hudojo, H (2001) bahwa pembelajaran matematika memiliki peran penting dan diajarkan disetiap jenjang seolah untuk diajarkan pada setiap jenjang kelas di sekolah supaya dapat menghadapi perubahan zaman yang terus berkembang. Oleh karena itu, sekolah dasar merupakan jenjang pendidikan awal, maka sangat penting pembelajaran matematika di sekolah dasar untuk diperhatikan agar tidak timbul masalah-masalah lebih lanjut. (Amir, 2015: 34)

Mempelajari matematika adalah penting karena dalam kehidupan sehari-hari, kita tidak boleh mengelak dari aplikasi matematika bukan itu saja matematika juga mampu mengembangkan kesadaran tentang nilai-nilai yang secara esensial. Sesuai dengan pendapat Mulyana (2004: 180) mengatakan matematika selain dapat memperluas cakrawala berpikir peserta didik juga dapat mengembangkan kesadaran tentang nilai-nilai yang secara esensial terdapat didalamnya. Hal ini juga didukung oleh pendapat Astuti (2018: 49) bahwa matematika merupakan suatu ilmu pengetahuan universal yang 
mendasari perkembangan teknologi modern, mempunyai peran penting dalam berbagai disiplin ilmu dan dapat melatih daya pikir manusia sesuai dengan tujuan dan fungsinya. Oleh karena itu, matematika sering diangap momok bagi banyak peserta didik karena membutuhkan daya pikir yang keras. Hal yang cukup memprihatinkan adalah sampai mahasiswa masih ditemukan bahwa matematika menjadi momok bagi mahasiswa. Mahasiswa masih beranggapan bahwa matematika merupakan pelajaran yang sulit, sukar, dan menegangkan (Suhendri, 2011: 29). Matematika bagi sebagian besar siswa dianggap sebagai pelajaran yang sulit untuk dipahami, sebab matematika selalu dihubungkan dengan angka dan rumus. Hal tersebut merupakan salah satu penyebab bahwa hasil belajar matematika masih belum memuaskan (Supriyanto, 2014: 166). Hal ini juga didukung oleh dari hasil wawancara yang peneliti lakukan pada kelas inovatif matematika dimana hasil dari wawancara menjelaskan bahwa mahasiswa tidak memilih kelas inovatif karena takut dengan matematika. Mahasiswa lebih memilih kelas konsentrasi yang lain bukan matematika seperti seni, anak kebutuhan khusus ataupun pendidikan anak usia dini. Berikut hasil wawancara. Di kalangan mahasiswa masih ditemukan mahasiswa menggangap matematika sebagai mata pelajaran yang sulit dan mata pelajaran. Hal ini nampak saat mahasiswa diminta melakukan simulasi mengajar di depan kelas. Mahasiswa memiliki kecenderungan memilih materi simulasi mengajar kelas 1, dengan alasan lebih mudah. Hasil wawancara adalah.

“"Saya ndak bisa hitung-hitung bu... hitung itu sulit bu” (Komunikasi pribadi, 19 Desember 2018)

“Matematika itu susah bu..” (Komunikasi pribadi, 19 Desember 2018)

"Bakat saya bukan matematika bu..” (Komunikasi pribadi, 19 Desember 2018)

"Pusing bu..." (Komunikasi pribadi, 19 Desember 2018)

Pernyataan-pernyataan tersebut mengungkapkan bahwa matematika masih menjadi momok bahkan sampai tinggkat tinggi. Tidak hanya itu saja, tetapi matematikapun masih menjadi momok bagi calon guru SD.

Peneliti juga sering mendapat keluhan dari beberapa dosen yang juga mengampu di PGSD, seperti dosen non Matematika yang juga menilai mahasiswa saat mengajar mata kuliah terpadu dan melakukan simulasi. Banyak ditemukan kesalahan-kelasalahan konsep. Berikut hasil wawancara peneliti dengan dosen.

"Ada mahasiswa bu, 3 x 4 menjawabnya $3+3+3+3$ bukan $4+4+4$ " (komunikasi pribadi dosen, 2019).

Hal ini memberikan kesan bahwa kualitas pendidikan mahasiswa masih jauh dari yang diharapkan.

Kesulitan dalam operasi hitung penjumlahan, pegurangan, perkalian dan pembagian. Salah satu solusi yang dapat dilakukan untuk memperbaiki konsep operasi hitung yaitu menurut Siregar, N.I (2002) dengan menggunakan Sempoa sangat cocok digunakan sebagai media untuk berhitung penjumlahan, pengurangan, perkalian dan pembagian. 
Masalah ditemukan peneliti pada saat melakukan penggalian data lebih dalam, peneliti juga menemukan kurangnya daya juang mahasiswa pada mata kuliah matematika dan sempoa. Mahasiswa lebih tampak lebih bersemangat saat bentuk tugas dan ujiannya dalam kelompok. Berdasarkan uraian masalah yang diungkapkan peneliti, mengindikasikan bahwa hal yang dibutuhkan mahasiswa adalah modul sempoa yang dapat membantu mahasiswa memahami matematika, Hal ini didukung oleh hasil penelitian yang dilakukan oleh Kusumayanti (2003) bahwa tingginya motivasi berprestasi pada anak sekolah dasar yang mengikuti pelatihan mental aritmatika. Sebanyak 36,67\% anak yang mengikuti pelatihan mental aritmatika mencapai kategori motivasi berprestasi tinggi, sedangkan yang mengikuti les matematika hanya $16,7 \%$. Hal ini sangat wajar sekali karena proses pembelajaran mental aritmatika, ada semangat untuk berkompetisi dan berusaha menjadi semakan baik selalu ditanamkan pada anak.

Menurut Ayi dan Sapriani (2015: 48), sempoa adalah sebuah alat kuno yang dipakai untuk berhitung yang dibuat dari rangka kayu dengan sederetan poros yang berisi manik-manik yang bisa digeser-geserkan. Sempoa merupakan alat hitung yang sering dijumpai dimana saja. Sempoa sendiri merupakan alat hitung yang sudah ada sejak zaman dahulu dan digunakan pada zaman 2.700-2.300 SM. Arima, N., \& Indrawati, D. (2018) juga menjelaskan bahwa sempoa merupakan sebuah alat menghitung dalam proses aritmatika. Pada mulanya, sempoa terbuat dari biji, batu serta logam namun sekarang sempoa diperbarui dengan berbahan bambu yang dilengkapi manik yang dapat digeser. Sempoa yang sering dijumpai saat ini merupakan sempoa yang berasal dari China yang dikenal dengan sebutan suanpan atau yang berarti nampan untuk berhitung. Sempoa atau sipoa merupakan alat hitung kuno yang terbuat dari rangka kayu dengan sederet poros berisi biji manik yang dapat digeser. Sempoa dapat digunakan untuk menyelesaikan permasalahan operasi hitung penjumlahan, pengurangan, perkalian serta pembagian. Dengan latar belakang ini, peneliti tertarik untuk melakukan penelitian dengan pengembangan modul sempoa bagi mahasiswa kelas Inovatif Matematika". penggembangan modul sempoa ini diharapkan dapat membantu pemahaman operasi hitung penjumlahan, pengurangan, perkalian serta pembagian pada mahasiswa. Menurut Endang, dkk. (2016) modul adalah panduan ajar yang disusun secara sistematis dan menarik yang mencakup isi materi, metode, dan evaluasi yang dapat digunakan secara mandiri. Hasil penelitian ini berupa modul sempoa yang dapat digunakan mahasiwa untuk memahami operasi hitung.

\section{METODE}

Penelitian ini menggunakan metode penelitian pengembangan yaitu berorientasi pada pengembangan produk pembelajaran yaitu Modul sempoa. Produk yang akan dihasilkan akan digunakan dalam mata kuliah inovatuf matematika. Pengemabngan produk berdasarkan analisis kebutuhan di kelas. Model pendekatan system yang dirancang dan dikembangkan oleh Dick \& Carey (2003). Dalam model tersebut terdiri atas sepuluh langkah, yaitu analisis kebutuhan dan tujuan, analisis pembelajaran, analisis pembelajar dan konteks, merumuskan tujuan informasi, mengembangkan instrumen, mengembangkan strategi pembelajaran, mengembangkan dan memilih bahan pembelajaran, 
merancang dan melakukan evaluasi formatif, melakukan revisi, dan evaluasi sumatif. Penelitian ini dilaksanakan dari bulan Maret sampai bulan November 2019. Subjek penelitian ini adalah mahasiswa PGSD Sanata Dharma semester 5.

\section{HASIL}

Hasil-hasil penelitian ini dapat dideskripsikan berdasarkan urutan pencapaian tujuan penelitian. Berdasarkan tujuan yang telah ditentukan ada tiga aspek yang diungkap dalam penelitian ini. Ketiga aspek tersebut meliputi pengelolahan sekolah, pelaksanaan pembelajaran, dan peran serta masyarakat.

Langkah-langkah dalam penelitian ini dengan mengadaptasi dari langkah-langkah Dick \& Carey yang terdiri dari 10 langkah dan diadaptasi menjadi 5 langkah, yaitu (1) melakukan analisis kebutuhan, (2) mendesain produk, (3) melakukan validasi dan evaluasi, (4) merancang dan membuat produk akhir, dan (5) melakukan implementasi.

Tujuan dari produk yang dikembangkan adalah berupa modul sempoa. Peneliti melakukan analisis pelaksanaan dan penggunaan sempoa sesuai dengan kebutuhan di lapangan. Modul yang ditentukan untuk membantu guru dan calon guru dalam menggunakan media sempoa.

Tahap desain produk meliputi tahap menentukan komponen modul, konsep penyampaian dan pengorganisasian materi, jenis kegiatan, tujuan kegiatan, jenis gambar dan juga media yang digunakan serta layout dari modul. Tahap ini menghasilkan desain produk awal berupa modul yang sebelumnya sudah dilakukan penyusunan instrumen penilaian produk untuk dijadikan pedoman dalam mendesain produk. Produk yang dikembangkan oleh peneliti adalah modul sempoa.

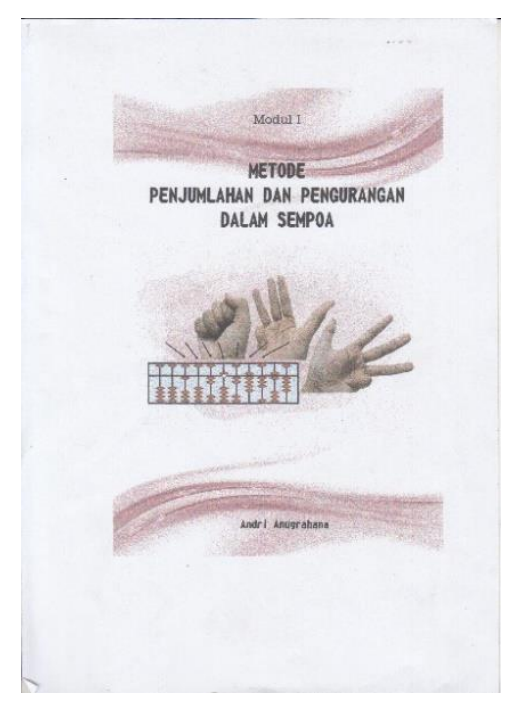

Gambar 1. Cover

Isi dalam modul sempoa ini adalah Sejarah dan macam-macam sempoa, tahapan pembelajaran dalam sempoa, proses pembelajaran dengan menggunakan sempoa, manfaat belajar metal aritmatika sempoa, aturan dalam penggunaan sempoa, konsep angka atau lambang bilangan, konsep 
nilai tempat dalam sempoa, bagian-bagian dan aturan sempoa, tabah kurang dalam sempoa, latihan kemahiran, latihan penjumlahan dan pengurangan sederhana, Pengenalan sahabat kecil dan sahabat besar, metode penjumlahan dan pengurangan sahabat kecil dan juga sahabat besar. tidak hanya itu saja tetapi juga ada latihan penjumlahan dan pengurangan sahabat gabungan yaitu sahabat kecil dan juga sahabat besar. Modul ini juga dilengkapi dengan latihan asas yaitu latihan asas penjumlahan dan juga latihan asas pengurangan.

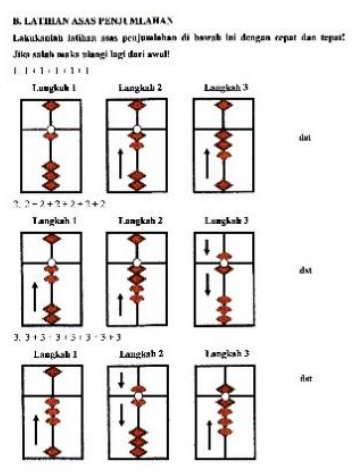

Gambar 2. Latihan Asas Penjumlahan

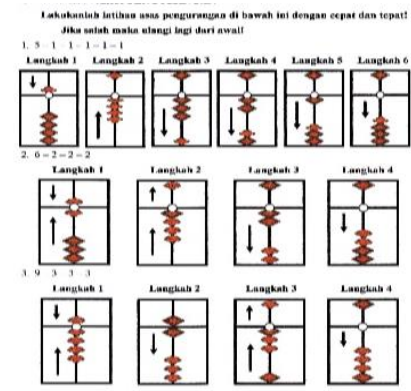

Gambar 3. Latihan Asas Pengurangan

Pengenalan sahabat kecil juga dikenalkan dalam modul sempoa. Sahabat kecil adalah dua bilangan yang jumlahnya 5. Digunakan untuk melakukan operasi tambah-kurang dengan faktor angka 1 sampai 4. Dimana sahabat kecil 4 adalah 1, sahabat kecil 3 adalah 2, sahabat kecil 2 adalah 3, dan sahabat kecil 1 adalah 4. Pengenalan sahabat kecil dapat dilihat pada gambar 4.

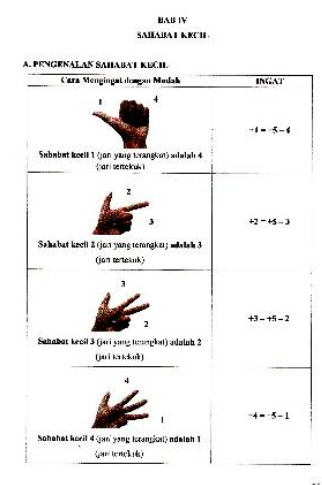

Gambar 4. Pengenalan Sahabat kecil 
Modul sempoa ini tidak hanya mengenalkan sahabat kecil saja tetapi jug mengenalkan sahabat besar. Sahabat besar adalah dua bilangan yang jumlahnya 10. Digunakan untuk melakukan operasi tambah kurang dengan faktor angka 1 sampai 9. Hal yang perlu diingat alam pengenalan sahabat besar adalah sahabat besar 1 adalah 9, sahabat besar 2 adalah 8, sahabat besar 3 adalah 7, sahabat besar 4 adalah 6, sahabat besar 5 adalah 5, sahabat besar dari 6 adalah 4, sahabat 7 adalah 3, sahabat 8 adalah 2, dan sahabat besar dari 9 adalah 1 .

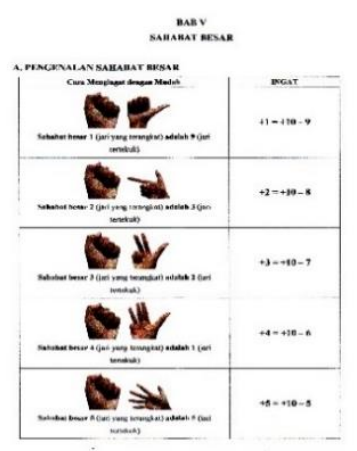

Gambar 5. Pengenalan Sahabat Besar

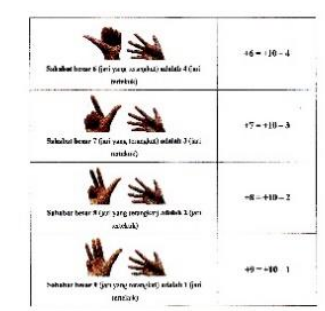

Gambar 6. pengenalan Sahabat Besar

Modul sempoa juga dilengkapi dengan tahap kemahiran. Kemahiran daam modul ini adalah kemahiran 1, kemahiran 2, kemahiran 3 dan seterusnya. Kemahiran penumlahan dan pengurangan juga ada dalam modul ini. Kemahiran penjumlahan seperti $1+4,3+2,2+3$ dan $4+1$. Sedangkan kemahiran penjumlahan seperti $5-1,5-2,5-3,5-4$.

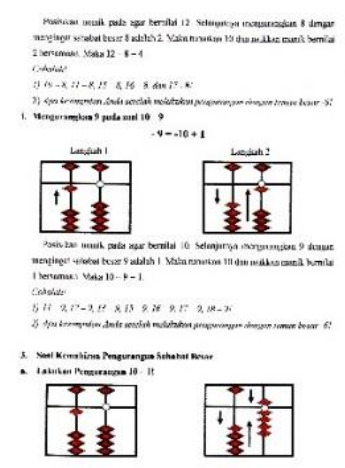

Gambar 7. Latihan Kemahiran dalam Pengurangan Sahabat Besar 
Validasi terhadap desain kelayakan produk dilakukan dengan cara meminta ahli Sempoa yaitu Agnes Ambar W. S.Pd. Salah satu guru di SD Kanisius Sorowajan dan pernah mengikuti kursus sempoa sampai pada level 8. Hasil saran dari validator digunakan untuk memperbaiki dan merevisi produk yang dikembangkan. Rangkaian selanjutnya adalah uji keterbacaan. Produk yang telah dinyatakan layak oleh validator selanjutnya diujikan kepada mahasiswa calon guru SD kelas Inovatif Matematika.

Tahap ini menghasilkan produk akhir berupa modul yang sudah direvisi berdasarkan kritik dan saran dari tahap validasi dan evaluasi penggunaan sempoa di kelas inovatif matematika. Produk akhir siap diproduksi secara masal dan dapat digunakan oleh guru maupun calon guru dalam mengajar sempoa.

Modul yang telah divalidasi oleh ahli diimplementasikan untuk mengetahui kualitas dari modul yang dihasilkan sesuai dengan tujuan dari modul untuk membantu guru dan calon guru memahami sempoa.

Validasi untuk mengetahui kuliatas produk yang peneliti kembangkan dilakukan sesuai dengan pedoman penyekoran skala lima menurut Sukardjo (2008:101). Tabel berikut merupakan Konversi Data Kuantitatif ke Data Kualitatif Skala Lima.

Tabel 1. Konversi Nilai Skala Lima (Sukardjo, 2008)

\begin{tabular}{cc}
\hline Interval Skor & Kategori \\
\hline $\mathrm{X}>\mathrm{Xi}+1,80 \mathrm{Sbi}$ & Sangat Baik \\
\hline $\mathrm{Xi}+0,60 \mathrm{SBi}<\mathrm{X} \leq \mathrm{Xi}+1,80 \mathrm{SBi}$ & Baik \\
\hline $\mathrm{Xi}-0,60 \mathrm{SBi}<\mathrm{X} \leq \mathrm{Xi}+0,06 \mathrm{SBi}$ & Cukup \\
\hline $\mathrm{Xi}-1,08 \mathrm{SBi}<\mathrm{X} \leq \mathrm{Xi}-0,06 \mathrm{SBi}$ & Kurang \\
\hline $\mathrm{X} \leq \mathrm{Xi}-1,80 \mathrm{Sbi}$ & Sangat Kurang \\
\hline
\end{tabular}

Keterangan:

Rerata Ideal (Xi): 1/2 (skor maksimal ideal + skor minimal ideal)

Simpangan Baku Ideal (SBi) : : 1/6 (skor maksimal ideal - skor minimal ideal)

X: Skor aktual

Skala penilaian terdiri dari lima pilihan untuk menilai "Modul Sempoa" yang dikembangkan, yaitu sangat baik (5), baik (4), cukup (3), kurang baik (2), dan sangat kurang baik (1).

Tabel 2. Tabel Kriteria Skor Skala Lima

\begin{tabular}{cc}
\hline Interval Skor & Kategori \\
\hline$X>4,21$ & Sangat Baik \\
\hline $3,40<X \leq 4,21$ & Baik \\
\hline $2,60<X \leq 3,40$ & Cukup \\
\hline $1,79<X \leq 2,60$ & Kurang \\
\hline$X \leq 1,79$ & Sangat Kurang \\
\hline
\end{tabular}


Hasil penelitian ahli dan aspek yang dinilai antara lain, (1) tujuan dan metode mendapat skor 4 dan dalam kategori "Sangat Baik", (2) cover buku divalidasi oleh ahli sempoa mendapatkan skor 3,5 dalam kategori "Baik", (3) isi buku mendapat skor 4 dalam kategori "Sangat Baik", dan (4) aspek bahasa dalam modul sempoa skor 3,75 dalam kategori "Cukup Baik". Apabila dirata-rata secara keseluruhan mendapatkan skor 3,81 dengan kategori "Sangat baik".

Adapun masukan untuk soal latihan masih ditemukan soal-soal yang tercampur. Misalnya saat membicarakan tentang teman kecil masih ada soal teman besar, baik jika dicek kembali soal antara teman kecil dan teman besar. Masukan yang kedua adalah masih ditemukan soal penjumlahan ataupun pengurangan dengan bilangan negatif. Sehingga tidak dapat dioperasikan. Pada modul sempoa ini hanya dibatasi pada operasi hitung penjumlahan dan pengurangan. Untuk operasi yang lain selain penjumlahan dan pengurangan belum dibahas dalam modul.

\section{KESIMPULAN}

Pengembangan modul sempoa membantu kemampuan berhitung lebih cepat, melatih daya imajinasi dan kreativitas, menyeimbangkan otak kiri dan otak kanan, meningkatkan konsentrasi belajar, koordinasi antara tangan dan otak, melatih kesabaran, meningkatkan percaya diri, menumbuhkan sikap jujur dan sportif serta berani, mengembangkan diri, meningkatkan motivasi berprestasi. Sempoa yang digunakan dalam pengembangan modul ini adalah sempoa bentuk 1-4 (1 manik sempoa di atas dan 4 manik sempoa di bawah). Sempoa ini mulai dipakai dan dimasyarakatkan di Jepang, sehingga dikenal sebagai sempoa Jepang.

Kualitas modul sempoa berdasarkan validasi ahli sempoa adalah (1) tujuan dan metode mendapat skor 4 dan dalam kategori "Sangat Baik", (2) cover buku divalidasi oleh ahli sempoa mendapatkan skor 3,5 dalam kategori "Baik", (3) isi buku mendapat skor 4 dalam kategori "Sangat Baik", dan (4) aspek bahasa dalam modul sempoa skor 3,75 dalam kategori “Cukup Baik”. Apabila dirata-rata secara keseluruhan mendapatkan skor 3,81 dengan kategori "Sangat baik".

Hasil ujicoba perorangan menyebutkan bahwa masih ditemukan soal-soal metode gabungan padahal soal penjumlahan atau pengurangan. Maka penting adanya pengecekan ulang untuk beberapa soal. Selain itu masih ditemukan juga soal-soal yang bersifat operasi hitung negatif. Modul sempoa ini dapat digunakan untuk calon guru ataupun untuk guru di sekolah dasar. Tidak hanya itu saja modul sempoa ini, dapat membantu siswa di sekolah dasar untuk memahami sempoa.

\section{DAFTAR PUSTAKA}

Ayi dan Safrina. 2015. Peningkatan Kemampuan Berhitung anak usis 5 - 6 tahun melalui Media Sempoa di TK Al-Ikhlas Lamhom Kecamatan Lhoknga Aceh Besar. Jurnal Pendidikan Volume 2.

Aji, W. N. (2016). Model Pembelajaran Dick and carrey dalam Pembelajaran Bahasa dan Sastra Indonesia. Kajian Linguistik dan Sastra, 1(2), 119-126. 
Amir, M. F. (2015, October). Pengaruh Pembelajaran Kontekstual Terhadap Kemampuan Pemecahan Masalah Matematika Siswa Sekolah Dasar. In Prosiding Seminar Nasional Pendidikan (pp. 34$42)$.

Arima, N., \& Indrawati, D. (2018). Pengembangan Media Pembelajaran Multiplication Stick Box pada Materi Operasi Hitung Perkalian Kelas III Sekolah Dasar. Jurnal Penelitian Pendidikan Guru Sekolah Dasar, 6(7).

Arima, N., \& Indrawati, D. (2018). Pengembangan Media Pembelajaran Multiplication Stick Box pada Materi Operasi Hitung Perkalian Kelas III Sekolah Dasar. Jurnal Penelitian Pendidikan Guru Sekolah Dasar, $6(7$

Astuti, A. (2018). Penerapan Realistic Mathematic Education (Rme) Meningkatkan Hasil Belajar Matematika Siswa Kelas VI SD. Jurnal Cendekia: Jurnal Pendidikan Matematika, 2(1), 49-61.

Dick and Carey. 2013. The Systematic Design of Intruction.

Endang dkk. 2016. Pengembangan Modul Pembelajaran Matematika dengan Pendekatan Inkuiri untuk membantu siswa SMA Kelas X dalam Memahami Materi Peluang. Jurnal Pendidikan.

Hudojo, H. 2001. Pengembangan Kurikulum dan Pembelajaran Matematika. Universitas Negeri Malang.

Kusumayanti, D (2003), Perbedaan Motivasi Berprestasi Antara Anak yang Mengikuti Pelatihan Mental Aritmatika dan Les Matematika, Skripsi, Universitas Muhammadiyah Malang, Malang

Mulyana, Rahmat. 2004. Mengartikulasikan Pendidikan Nilai. Bandung: Alfabeta.

Pramita, D. (2017). Pengenalan dan Pelatihan Berhitung dengan Jarimatika dan Sempoa di Sdn 10 Ampenan. JMM (Jurnal Masyarakat Mandiri), 1(1), 46-51

Siregar, N. I. (2002). Pengaruh Pelatihan Sempoa (Abakus) Terhadap Prestasi Belajar Matematika. Yogyakarta: UGM Tesis tidak diterbitkan.

Suhendri, H. (2011). Pengaruh kecerdasan matematis-logis dan kemandirian belajar terhadap hasil belajar matematika. Formatif: Jurnal Ilmiah Pendidikan MIPA, 1(1), 29-39

Supriyanto, B. (2014). Penerapan Discovery Learning Untuk Meningkatkan Hasil Belajar Siswa Kelas VI B Mata Pelajaran Matematika Pokok Bahasan Keliling Dan Luas Lingkaran di Sdn Tanggul Wetan 02 kecamatan Tanggul Kabupaten Jember. Pancaran Pendidikan, 3(2), 165-174.

Sukardjo. (2008). Kumpulan materi evaluasi pembelajaran. Yogyakarta: Universitas Negeri Yogyakarta. 